\title{
Low-fidelity bench models for basic surgical skills training during undergraduate medical education
}

\section{Modelos de bancada de baixa fidelidade para o treinamento de habilidades cirúrgicas básicas durante a graduação médica}

Rafael Denadal, ACBC-SP1,2; Rogério Saad-Hossne, TCBC-SP3; Andréla Padillha Todelo; Larissa Kirylko4; Luís Ricardo Martinhão SOUTO, TCBC-SP4

\section{A B S S T R A C T}

\begin{abstract}
It is remarkable the reduction in the number of medical students choosing general surgery as a career. In this context, new possibilities in the field of surgical education should be developed to combat this lack of interest. In this study, a program of surgical training based on learning with models of low-fidelity bench is designed as a complementary alternative to the various methodologies in the teaching of basic surgical skills during medical education, and to develop personal interests in career choice.
\end{abstract}

Key words: Education. Students. Surgery. Ability. Training.

\section{INTRODUCTION}

In recent decades, there have been studies ${ }^{1,2}$ showing a significant reduction in the number of medical students choosing general surgery as a career. Several reasons have been reported by undergraduates against surgical career, such as it being a "very stressful area that requires many efforts and unpredictable work hours" ${ }^{1}$. These statements show that undergraduates are currently more concerned with the quality of their lives outside of work and therefore pursue careers that allow this lifestyle ${ }^{2}$. Moreover, the decrease of the space of surgical education in universities' curricula has contributed to the lack of interest of students by surgical careers because medical schools cannot effectively demonstrate how the surgeon can balance work and personal life ${ }^{3}$.

According to future projections, there will be a significant number of unfilled vacancies in General Surgery Residency as a direct result of this reduction in interest in the surgical area and, therefore, general surgeons will be lacking in the next years ${ }^{1,4,5}$. In this context, some proposals have been described to address this lack of interest $1,3,4,6,7$.

Among the methodologies that can potentially attract students to the surgical career, some authors 6,7 have shown that exposure of students to the surgical context positively influences career choice. Among the different aspects of this exposure (eg, promote surgical guidance and basic surgical knowledge ${ }^{8}$ ), the teaching and learning of basic surgical skills is of particular interest because these skills are the foundation upon which the rest of the skills will be built 8 . Moreover, regardless of the intentions of career, mastery of these skills is beneficial both to the future doctors and their patients ${ }^{9,10}$.

In this context, several international proposals (eg, American Surgical Association Blue Ribbon Committee Report on Surgical Education, Medical School Objectives Project and National Competency-Based Learning Objective Catalogue for Medicine ${ }^{12}$, among others ${ }^{4,6,11,12}$ ) have set minimum prerequisites that medical graduates must master (eg, thoracentesis and suturing lacerations). In Brazil, the National Curriculum Guidelines for Medicine Graduation ${ }^{13}$ also state that medical training has the aim of providing the professional knowledge required to perform essential surgical procedures for ambulatory care.

Despite the importance of the subject, a large percentage of medical students do not acquire basic surgical skills during their training ${ }^{14,15}$ and most general practitioners who perform outpatient surgery received no formal surgical training ${ }^{16}$. With increasing number of outpatient surgeries general practitioners need to perform to treat different skin lesions ${ }^{17}$, there is a clear need to establish an educational program to train and refine basic surgical skills (eg, incision

1. Institute of Craniofacial Plastic Surgery, SOBRAPAR Face and Skull Hospital, Campinas, São Paulo State - SP; Resident Physician, Department of Surgery; 2. Dr. Mario Gatti County Hospital (HMMG), Campinas, São Paulo State - SP, Brazil; 3. Postgraduation Program in General Surgery (PPG-BGC), Department of Surgery, Faculty of Medicine of Botucatu, Julio de Mesquita Filho Paulista State University (FMB-UNESP), Botucatu, São Paulo State - SP, Brazil; 4. Division of Plastic and Reconstructive Surgery, Department of Surgery, Faculty of Medicine, University of Marilia (UNIMAR), Marilia, Sao Paulo State - SP, Brazil. 
techniques, suturing and biopsy and principles on skin reconstruction), which are essential to achieving these outpatient procedures during medical school ${ }^{14,16}$.

While there are efforts to standardize surgical education ${ }^{4,6,11-13}$, the ideal training methodology remains unclear, there being different methods to teach surgical skills during medical school ${ }^{8}$. Considering that learning in living patients (traditional methodology teaching) violates ethical and medico-legal aspects ${ }^{18}$ and that the acquisition of surgical skills directly with patients has generated anxiety (" fear of harming the patient") in medical students ${ }^{15}$, the teaching of basic surgical procedures seems to be the ideal field for the application of simulation-based training ${ }^{4,19}$.

With this purpose (simulated surgical training), numerous inanimate models of bench have been used as alternative tools ${ }^{20-28,}$ since the practice in live animals and human cadavers is associated with risk of infections, high costs, need for specialized facilities and ethical and legal issues and the use of virtual reality simulators is hampered by the high financial cost and lack of access ${ }^{20}$. However, none of these models allows surgical skills to be thoroughly learned ${ }^{14,16}$, there being no ideal simulator (or a teaching program) $^{8}$

In view of these considerations, as there are difficulties in changing university curricula ${ }^{10}$ and since new possibilities in the field of the simulated surgical education need to be explored to impact positively on the quality and safety of surgical practice ${ }^{29}$, the aim of this study was to develop a program of education-learning grounded in basic surgical skills training in low-fidelity bench models to introduce and improve the surgical skills of students in training as well as to develop personal interests in career choice.

\section{simulation}

Design of the training program based on

The purpose of this program is based on a combination of self-directed training with feedback from instructors, over several sessions (days, weeks or months) of teaching and learning, interspersed with periods of rest 30,31 , preferably in early graduation ${ }^{4,9}$, as it has been shown that the majority of medical students choose the specialty after the third year of medical school ${ }^{4}$. The basic structure of each training session consists of four steps: 1) verbal learning directed by instructor based on learning materials, diagrams, books, online tools and videos narrated by experts; 2) instructor-led training on bench models; 3 ) self-directed training outside the classroom, for example, at home; 4) training focused on procedures performed out-of-class by a instructor - after the out-of-class practice, the undergraduate must bring the bench model with the procedures performed for the specific technical factors to be assessed and constructive feedback provided. The order of these sessions may vary and steps can be adapted according to the needs of students (individual or groups).
In order to standardize the process of teaching, we recommend the adoption of an instructor for every four students ${ }^{32}$. The undergraduates should be distributed around rectangular tables, providing mobility for both the instructor to demonstrate the surgical technique and to clarify any doubts individually or in subgroups. During the steps of training, the instructor should explain the advantages and disadvantages of each specific technique and concepts about the appropriate choice of surgical materials. One should also highlight the importance of the correct use of surgical instruments.

\section{Learning goals}

As training in basic skills can lead to better performance of more complex tasks ${ }^{30}$, it is important to set clearly defined goals of education in increasing order of difficulty ${ }^{33}$, to be distributed in different training sessions. Thus, as the student acquires skills considered simpler, the degree of difficulty should be increased. The process of teaching and learning should be totally geared for the student; the practice should be individualized, deliberate, repetitive and participatory ${ }^{33}$. Initially, the goals may be similar for all group members. However, in subsequent sessions, proposals may vary according to the needs of each student.

According to the various existing recommendations in the literature on the minimum needs of training medical students $4,6,11-13$, the basic surgical skills as outlined in this training program include, in order of increasing complexity and refinement, the teaching of knots, incisions, suturing, biopsies, surgical flaps and grafts.

\section{Bench models of low fidelity}

In recent years, various bench models have been

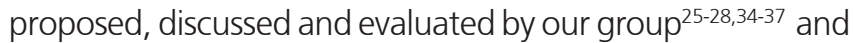
others ${ }^{21-24}$. In this program, we adopted three low-fidelity bench models made of fruits / vegetables, ethylene vinyl acetate (EVA) plates and rubberized plates ${ }^{25-27}$ as teaching platforms, as they provide the three-dimensional understanding of all procedures and also allow students to learn to respect the different layers of the skin (epidermis, dermis, subcutaneous tissue and muscles) during practice. Based on the experience acquired by the group 25-28,34-37, besides strengthening the various applications of these three bench models ${ }^{25-27}$, complementary features are also outlined.

For making each type of bench one need only the (synthetic or organic) material chosen, a styrofoam plate, needles and a paint brush (or ballpoint pen). Generally, synthetic materials are used in the manufacture of decorative objects. Synthetic and organic materials are easily purchased at supermarkets and Crafts shops, respectively.

For materials not to slipp during practice, they should be set in styrofoam with needles. Skin lesions can be simulated through drawings on the surfaces of the models, in order to make it more attractive and enriching 
surgical training. For a better coaptation of the edges of the "wound", training of suturing techniques should be preferably performed close to the edges of the synthetic plates (EVA and rubberized) and for the simulated practice of surgical flaps square patches of approximately $10 \mathrm{~cm}^{2}$ must be made. Furthermore, in order to simulate the different layers of the skin, four or more synthetic plates must be superimposed (Figure 1). The peels of fruits / vegetables also simulate the skin layers.

\section{Manipulation of surgical instruments}

For training, each undegraduate must receive basic surgical instrument kit consisting of a Mayo scissors, a Mayo-Hegar needle holder, anatomical and toothed types tweezers, scalpel handle and blade and needled sutures. In addition to properly manipulate the surgical instruments, it is important that during the various stages of teachinglearning students also learn about the proper choice of instruments, as, for example, the use of scalpel blades numebrs 11, 15 and 23, monofilament and multifilament surgical sutures and tips (blunt or sharp) of surgical sutures needles specific for each type of procedure.

\section{Training incisions, sutures and surgical}

\section{knots}

The models allow the training of incisions (linear, circular, elliptical, vertical and horizontal), surgical knots (index finger, middle finger, surgeon and shoemaker) and different sutures, such as single stitches, vertical (Donati and McMillen), modified vertical (Allgöwer), horizontal Ushaped, X-shaped (crossed), Greek bar, simple and anchored running sutures, intradermal and subdermal (Figure 2).

The training of incisions, sutures and surgical knots can occur simultaneously. First, the student must select an area simulating an injury. With the scalpel the model is incised, which facilitates teaching the proper way to handle the instrument, its position with the "skin " (cutting angle between $30^{\circ}$ and $60^{\circ}$ ), the way of the cut (steady, without sawing movement) and the depth of the incision 21,38. Following, the created defects are repaired with the placement of stitches, also applying important technical aspects to promote proper healing, such as meticulous handling of tissues, positioning the needle in the needle holder, angle of entry of the needle into the "skin " $\left(90^{\circ}\right)$, exit of the needle in a equidistant point from its entry point and approximation and eversion of the wound edges with appropriate tension ${ }^{16,39}$. The completion of the sutures can be made manually or performed with the aid of instruments. The manual knots should comply to the following principles: 1) equal movements of opposite hands perform a perfect knot; 2 ) the tip of the suture that switches sides after running the first semi-knot must return to the initial side to make the other semi-knot; 3 ) knots must be firm, but without tension on the tissue (when in vivo, the excessive tension may result, for example, in the avulsion of a blood vessel) ${ }^{40}$.

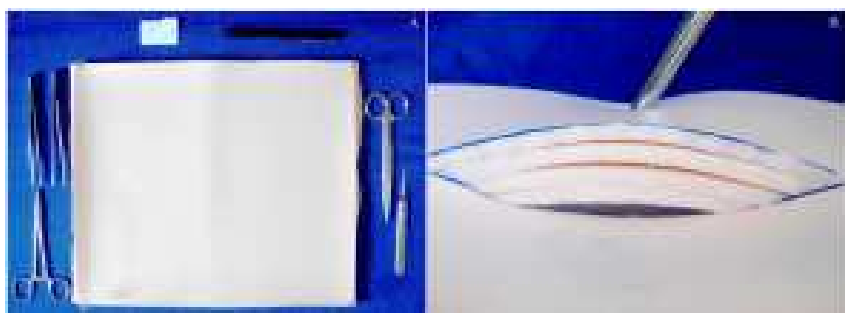

Figure 1 - Synthetic bench model made with rubberized plates. A) Rubber plates overlapping and fixed with needles, B) Simulating the different layers of the skin.

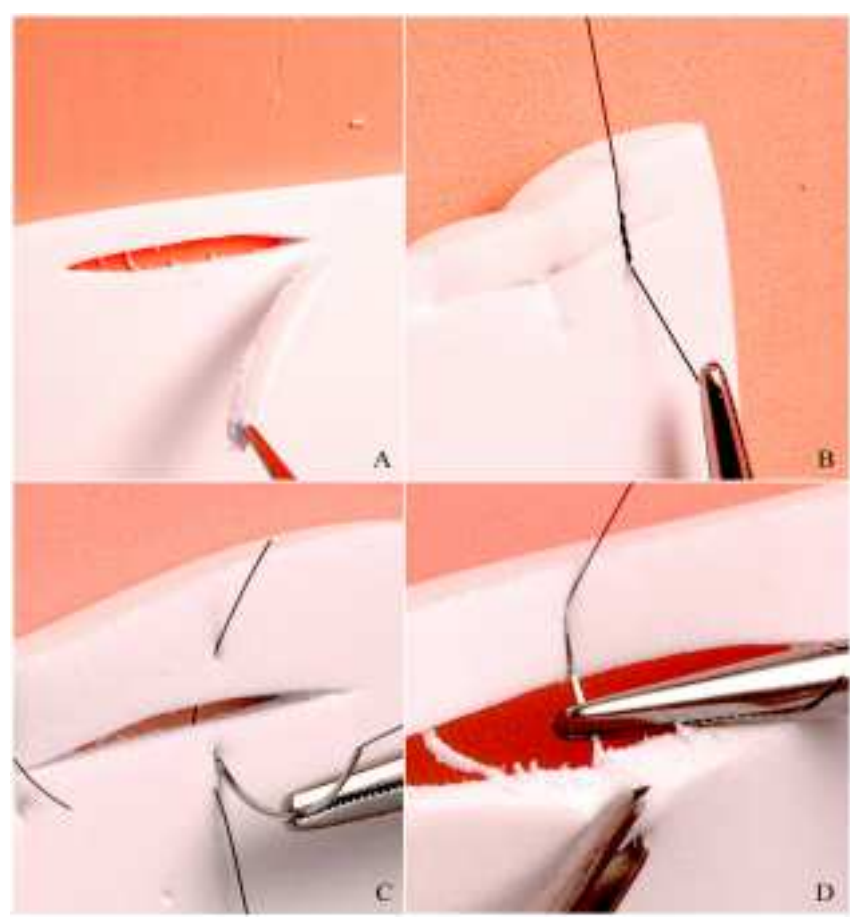

Figure 2 - Synthetic bench model made with plates of ethylene vinyl acetate for training of suture techniques. A Defect created near the edge of the model. Stitches $B$ ) simple C) Donatti and D) inverted subdermal (note the thickness of the material and the simulation of different layers of the skin).

Training of biopsy techniques and of principles of skin reconstruction

The training techniques of biopsy (elliptical and circular excisional and incisional, and with and without safety margins) should be performed on models, always following previously established requirements (Table 1) 21,38,41,42. The bench models also allow the introduction of students to skin reconstruction with surgical grafts and flaps.

Grafts - when facing a skin defect, students should plan on making a stamp, mesh or strip graft. The graft should be removed intact from the donor area with a scalpel blade, Blair knife or dermatome; students should train different pressures on tissues and angles between the blade and the skin in order to produce grafts of varying sizes and thicknesses. After obtaining the graft, it must be placed in the receiving area and shaped such that the edges 
are well coapted on all sides of the recipient bed. Further on, adequate graft fixation should be performed to reduce the dead space ${ }^{43}$. Simulation of the Brow dressing (pressure dressing for skin grafts) should also be part of training ${ }^{37}$.

Flaps - when facing a skin defect, conducting a transposition flap (Z plasty, W-plasty, rhomboid and bilobed), Rotation flap, Forward flap (T-plasty and VY) or island flap should be planned based on schemes ${ }^{44}$. Then, the markings are incised, the flap is moved to fill the defect and simple stitches should fix the flap, carefully avoiding tension to its pedicle (Figure 3).

\section{Diagnosis and treatment of skin lesions based on simulation}

After acquiring the techniques of incisions, surgical knots, sutures, biopsies, surgical flaps and grafts alone and repeatedly until such skills can be performed effectively and quickly, and almost automatically, students can train diagnosis and treatment of simulated skin lesions through the union of the skills learned, since it has been shown that for the training of a complete procedure this can be broken down into several components ${ }^{45}$.

Different skin lesions can be simulated in bench models. As studies ${ }^{46,47}$ have shown that medical schools are deficient in education focused on proper approach of necrotic wounds and nonmelanoma skin cancer ${ }^{26,37}$, our group has been proposing the simulated training of these lesions in order to increase interest and knowledge in graduates training.

Necrotic wounds - the surface of the bench model chosen should be carefully burnt to simulate a necrotic tissue. Students must perform surgical debridement of the affected areas, taking care not to damage the healthy tissue.

Nonmelanoma skin cancer - the student should make an excisional biopsy with predetermined security margins because this is considered the standard diagnostic and therapeutic procedure for most of these lesions ${ }^{42}$. For this, the student must follow the sequence of marking the safety margins forming an ellipse, incision of the margins,
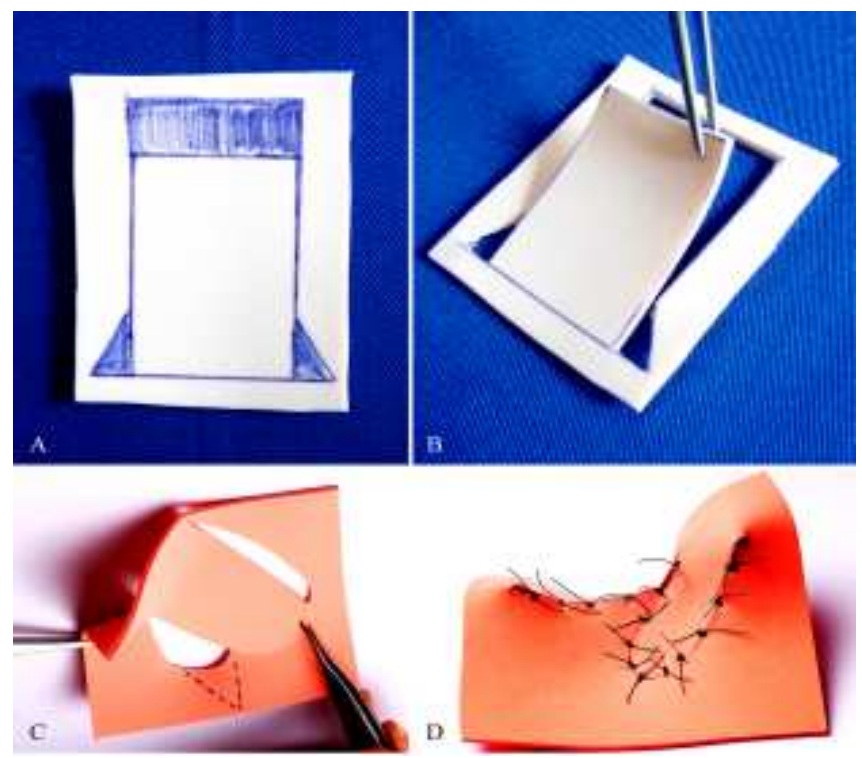

Figure 3 - Synthetic bench models made of rubberized plates (above) and ethylene vinyl acetate (below), simulating surgical flaps. A) Marking of the margins of an advancement flap; B) Elevation of the flap; C) Simulation of lifting of a lobed flap; and D) Final appearance after suture.

Table 1 - Technical principles of teaching-learning of classical elliptical excisional biopsy 21,38,41,42.

Procedure Skilss

Drawing the ellipse

Safety margins

Incision of the ellipse

Excision of the ellipse
A) The ellipse must be formed by two arcs;

B) The arcs must be symmetrical in relation to the midline that separates them and must meet the ends forming a convexity;

C) The curvature used should be based on a length-width ratio of 3:1 to 4:1 of the ellipse formed;

D) One should use a $30^{\circ}$ angle at the ends of the ellipse (the intersection of the arcs).

A) A line shall be marked around the periphery of skin lesion to delimit the safety margins;

B) According to the current recommendations for surgical resection of most cases of NMSC, extensions of safety margins should be 2-10 mm.

A) Smooth moves with a scalpel;

B) Cutting angle between $30^{\circ}$ and $60^{\circ}$;

C) Cuts of the subcutaneous tissue with only 1 or 2 movements;

D) Avoid damaging of the edges of the ellipse.

A) Handle tissue gently to avoid damaging the epidermis;

B) Cuts in the same plane while removing the tissue;

C) Resect the same amount of tissue in all areas of the wound.

NMSC = non-melanoma skin cancer. 
careful excision of the lesion and primary closure of the defect created by suture or repair of the defect with flap transposition, rotation or advancement or graft placement (Figure 4).

\section{Feedback given by instructors}

In the context of simulation-based surgical education, feedback from instructors is associated with a faster and more effective learning and with greater retention of learned knowledge ${ }^{33}$. Thus, all students must receive feedback during and at the end of each stage of training ${ }^{33}$. instructors must examine specific movements, noting inadequate elements (eg, marking lines and results of procedures ed can serve as evaluation parameters) and shall, in sequence, provide constructive feedback (identify and correct any technical errors) to students. Thus, graduates perfect the skills based on their mistakes and can train again and again, acquiring skills over time. Concurrent with the feedback, it is important to encourage students to take questions during practice and after realization of extracurricular tasks.

\section{Assessment and accreditation of the training process}

We should emphasize the importance of an objective evaluation during and at the end of the whole process of teaching and learning from each surgical skill proposed in order to measure the level of acquisition of the skills taught. For this purpose, the Global Rating Scale (GRS) may be employed ${ }^{48,49}$. With this scale it is possible to evaluate the performances of students in eight key areas through a Likert scale of 5 points, 1 being the minimum score and 5 the highest, so that the maximum score achieved is 35 (Table 2). Instructors can apply it to the end of each training session and in subsequent sessions follow up the students skills gain and specific points that merit further attention within the eight reviewed. Moreover, this scale ${ }^{48,49}$ can also be used as a certification tool; for an individual task, the candidate must achieve a score of 24 or more to be considered competent ${ }^{50}$. Accordingly, if the medical student meets the predefined criteria based on objective assessment, he/she can proceed to the next stage of training (considered more complex). However, if the student is not able to proceed, one must repeat the training focusing on specific deficits and then a new objective assessment should be applied.

Still in the sphere of objective evaluation of training, marking lines can serve as an evaluation parameter, and one should identify and correct incisions that do not follow them ${ }^{26,27,37}$. Furthermore, a characteristic of bench models that could be considered a problem (tearing potential) is actually an advantage, because it only occurs when the student makes a wrong move, for example, application of excessive force. This feature can serve as an evaluation mechanism with feedback for improving skills 25-28,37.

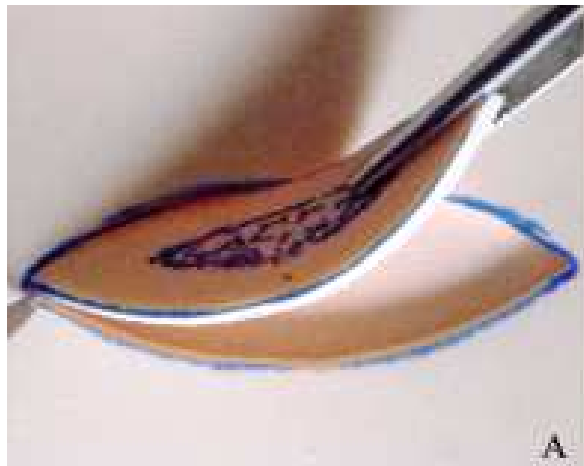

A

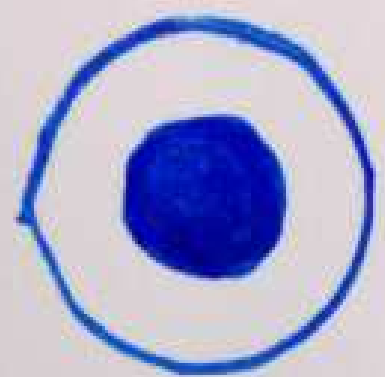

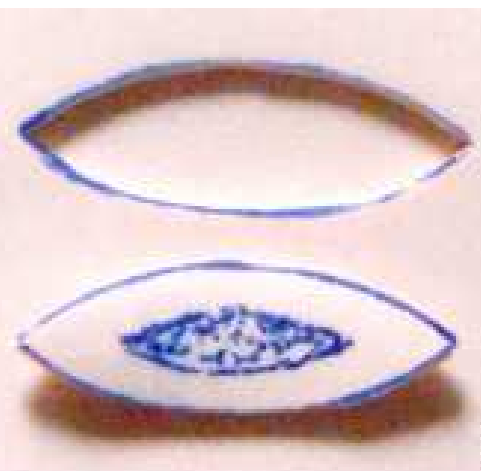

B

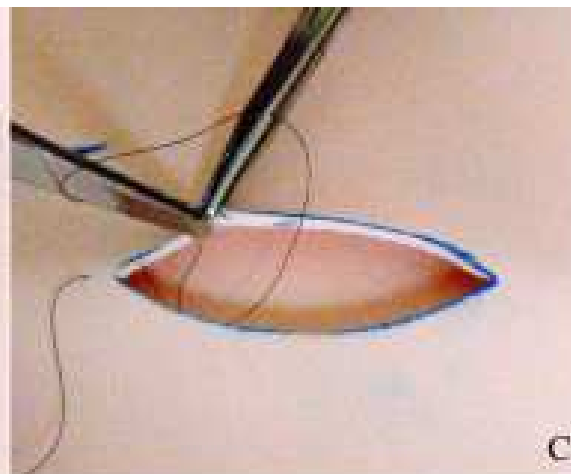

C

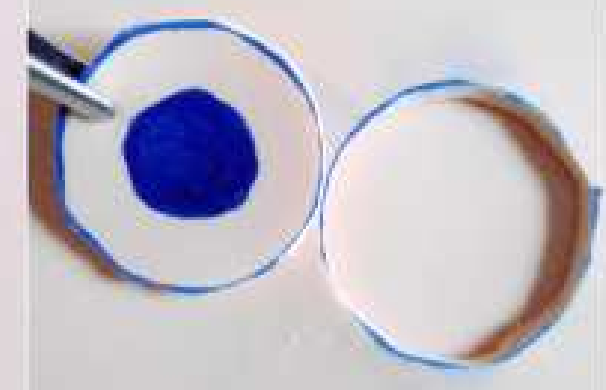

E

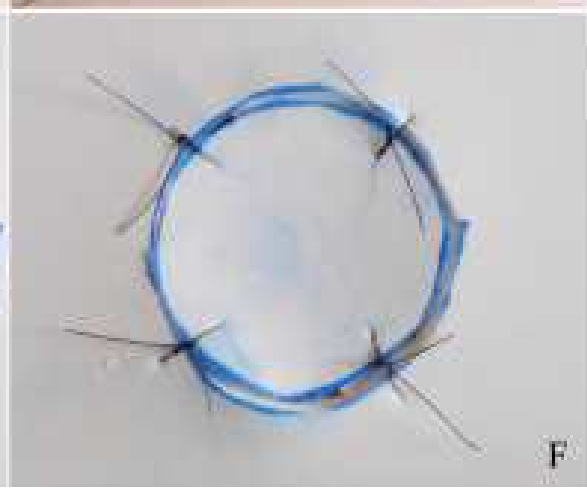

Figure 4 - Model of a synthetic bench made ??with rubberized plates simulating a "skin tumor" with a diagnosis of non-melanoma skin cancer, its resection and reconstruction of the defect created. (A and D) "Cutaneous neoplasm" and the safety margins for resection. (B and $E$ ) "Cutaneous neoplasm" removed intact with a full thickness plate excision (note the intact second plate at the bottom of the defect). Correction of the defect with intradermal suture (C) and a "skin graft" (F). 


\section{DISCUSSION}

In the last two decades, the efficiency, effectiveness and ethics of the Halstedian surgical training model exemplified by the phrase "see one, do one, teach one" has been increasingly questioned ${ }^{6}$, and based on the reduction of surgical residents experience, a new paradigm of surgical training ("do one, teach one") was recently proposed ${ }^{51}$. Accordingly, although the experience and evaluation in the operating room should remain the "gold standard" of medical education, the old method of surgical training has been replaced by a model of competence development based on simulation ("see one, simulate many, do one competently, and teach everyone") 52 .

At this scenario, since the mastery of basic surgical skills should be part of the arsenal of all doctors and it is recommended that the acquisition of these skills occurs outside the actual environment (simulation-based training) before any procedures in patients ${ }^{20}$, the primary focus of this study was to propose a program for teaching the principles of surgery during medical degree through training on bench models of low fidelity. In order to increase the arsenal of surgical skills of medical students in training and also the exposure of the surgery, this proposal and how the way bench models are applied can be incorporated and adapted to complement teaching and learning methodologies already established in the various institutions.

Having been demonstrated that retention of surgical skills is more robust when acquired in an interleaved manner, with resting periods (several training sessions), instead of teaching in a single time ${ }^{31}$, this form of training has been adopted in this proposal with the aim to increase the retention and improvement of surgical skills taught ${ }^{30,31}$. However, some factors, such as high financial cost and lack of time and shortage of surgery teachers (traditional instructor) ${ }^{29-31}$, have been described as factors limiting the implementation of this simulated training strategy.

One way to partially reduce costs, especially in underdeveloped and developing countries $8,25-27,37$ is the adoption of low cost bench models, as used in this proposal. A broad range of bench models has been described with similar purposes ${ }^{21-28}$. These models differ in the level of fidelity when compared with living a human, there being those high fidelity (pork and chicken skins, ox tongue and surgical specimens discarded in surgical procedures) and others of low-fidelity (EVA and rubberized plates and organic material) ${ }^{21-28}$

Despite the intuitive belief that "the more realistic the better", in the realm of simulation-based education, skills acquisition should be measured through an objective method ${ }^{53,54}$. Our group ${ }^{34-36}$ and others ${ }^{18,55,56}$ have objectively demonstrated that beginners in surgical practice acquire surgical skills in bench models, regardless of model fidelity. Moreover, it was also demonstrated that the transfer of surgical skills for the clinical setting is independent of model fidelity used as a teaching tool $18,55,56$, so the choice of a particular model should not be based solely upon its fidelity. Other requirements such as availability, versatility, reproducibility, minimal need for storage and costs should be considered in this choice. In this context, models of high fidelity bench made from parts of deceased animals have their use limited or derailed due to the need for structure, space and proper conditions for storage and bioethical and legal aspects $20,26,27$. On the other hand, the low fidelity simulation being simple, portable, reproducible, versatile, of easy accessibility and handling 20,26,27, can provide more material and opportunity for repetitive training in any environment (not only in classrooms), without compromising results ${ }^{55}$.

The backstage and latex gloves models are also of low-fidelity and low financial cost. However, they do not allow the training of three-dimensional procedures such as subdermal sutures and surgical flaps. There are other industrialized low-fidelity simulators allowing threedimensional training. However, such models have a higher financial cost. The cost of fruits and vegetables vary mainly according to regional availability and seasonality 26 .

Regardless of the characteristics discussed, the authors believe that the low-fidelity bench models used in this training program should not necessarily replace the simulators used in different educational institutions. In fact, the proposal is that they are complementary or adapted to existing models. The manner of use of the models suggested in this study was designed to facilitate the teaching-learning for beginners on training surgical techniques, and as students acquire the pre-established requirements (simple skills), training can be increased with teaching of more complex procedures in the models themselves or in other simulators. For example, in those training programs that use parts of deceased animals as platforms for education in surgical technique laboratories (or classrooms) ${ }^{21-24}$, low-fidelity models can be used for training sessions at home.

Although costs can be reduced by adopting cheap simulators, time availability remains a problem for surgery teachers ${ }^{30}$. Feedback generated by computers could be an option to reduce the time of supervised learning. However, besides the high cost for obtaining, retention of skills over time is significantly greater when learned through direct feedback from an instructor ${ }^{57}$. Accordingly, the incorporation of resident physicians 19 or trained non-physicians (laboratory technicians or medical students in a monitoring format) ${ }^{26.37}$, is an alternative that can reduce the number of teaching surgeons who are transferred from patient care for simulation environments, without compromising learning 29. With this measure, surgeons would focus on teaching complex tasks and cognitive aspects of surgical education (decision making), which are not to be taught by the nonmedical instructor ${ }^{26}$. Encouraging the practice outside the classroom, at home, as previously proposed by our group $25-28,34-37 \mathrm{can}$ also help reduce the time of supervised teaching. 
The concept of "surgical competence" implies the combined mastery of different skills, including knowledge, decision making, communication, leadership and dexterity ${ }^{58}$. Regardless there are statements such as "a skillfully performed operation is 75\% decision making and $25 \%$ dexterity " and "surgeons must be skilled and have a steady hand and a clear vision", all these parameters should be measured ${ }^{59}$. Nevertheless, although there are regular, formal and mandatory examinations to test knowledge and decision making ${ }^{59}$, the evaluation of acquisition of technical skills, one of the fundamental scopes of surgical training ${ }^{59}$, is not completely standardized ${ }^{50,59}$.

In the traditional model of surgical training, residents performed surgery in a large number of patients under the supervision of a preceptor, which subjectively determined when they reached the technical proficiency

Table 2 - Global Rating Scale $\quad$ G8.49 for the objective assessment of the acquisition of surgical skills.

Please circle the number corresponding to the performance of the candidate:

\begin{tabular}{|c|c|c|c|c|c|}
\hline & 1 & 2 & 3 & 4 & 5 \\
\hline \multirow[t]{2}{*}{ Respect for tissue } & $\begin{array}{l}\text { Often used unnecessary } \\
\text { force on tissue or caused } \\
\text { damage by inappropriate } \\
\text { use of instruments }\end{array}$ & & $\begin{array}{l}\text { Careful handling of } \\
\text { tissue but occasionally } \\
\text { caused inadvertent } \\
\text { damage }\end{array}$ & & $\begin{array}{l}\text { Consistently handled } \\
\text { tissues appropriately. } \\
\text { with minimal damage }\end{array}$ \\
\hline & 1 & 2 & 3 & 4 & 5 \\
\hline \multirow[t]{2}{*}{ Time and motion } & Many unnecessary moves & & $\begin{array}{l}\text { Efficient time and } \\
\text { motion, but some } \\
\text { unnecessary moves }\end{array}$ & & $\begin{array}{l}\text { Economy of movement } \\
\text { and maximum efficiency }\end{array}$ \\
\hline & 1 & 2 & 3 & 4 & 5 \\
\hline \multirow[t]{2}{*}{ Instrument handling } & $\begin{array}{c}\text { Repeatedly makes tentative } \\
\text { or awkward moves with } \\
\text { instruments }\end{array}$ & & $\begin{array}{l}\text { Competent use of } \\
\text { instruments, although } \\
\text { occasionally appeared } \\
\text { stiff or awkward }\end{array}$ & & $\begin{array}{l}\text { Fluid moves with } \\
\text { instruments and no } \\
\text { awkwardness }\end{array}$ \\
\hline & 1 & 2 & 3 & 4 & 5 \\
\hline \multirow[t]{2}{*}{ Suture technique ${ }^{*}$} & $\begin{array}{l}\text { Clumsy and insecure, } \\
\text { inadequately tying knots and } \\
\text { inability to maintain tension }\end{array}$ & & $\begin{array}{l}\text { Careful and slow with } \\
\text { most knots placed } \\
\text { properly with proper } \\
\text { tension }\end{array}$ & & $\begin{array}{l}\text { Excellent control of the } \\
\text { suture, with proper } \\
\text { placement of knots and } \\
\text { correct tension }\end{array}$ \\
\hline & 1 & 2 & 3 & 4 & 5 \\
\hline \multirow[t]{2}{*}{$\begin{array}{l}\text { Elliptical excision biopsy } \\
\text { technique }{ }^{* *}\end{array}$} & $\begin{array}{l}\text { Lack of knowledge about the } \\
\text { parameters ( }<2 \text { mm or }>10 \\
\text { mm margins); angles much } \\
\text { different from } 30^{\circ} ; \text { length- } \\
\text { width ratio very different } \\
\text { from } 3-4: 1\end{array}$ & & $\begin{array}{l}\text { Adequate margins (2- } \\
10 \mathrm{~mm} \text { ); angle at the } \\
\text { ellipse ends slightly } \\
\text { different from } 30^{\circ}: \\
\text { length-width ratio } \\
\text { slightly different from } \\
3-4: 1\end{array}$ & & $\begin{array}{l}\text { Adequate margins (2- } \\
10 \mathrm{~mm}) ; 30^{\circ} \text { angles at } \\
\text { the ellipse ends; length- } \\
\text { width ratio } 3-4: 1\end{array}$ \\
\hline & 1 & 2 & 3 & 4 & 5 \\
\hline \multirow[t]{2}{*}{$\begin{array}{l}\text { Flow of operation and } \\
\text { forward planning }\end{array}$} & $\begin{array}{l}\text { Frequently stopped } \\
\text { operating or needed to } \\
\text { discuss next move }\end{array}$ & & $\begin{array}{c}\text { Demonstrated ability } \\
\text { for forward planning } \\
\text { with steady } \\
\text { progression of } \\
\text { operative procedure }\end{array}$ & & $\begin{array}{l}\text { Obviously planned } \\
\text { course of operation with } \\
\text { effortless flow from one } \\
\text { move to the next }\end{array}$ \\
\hline & 1 & 2 & 3 & 4 & 5 \\
\hline \multirow[t]{2}{*}{$\begin{array}{l}\text { Knowledge of specific } \\
\text { procedure }\end{array}$} & $\begin{array}{l}\text { Deficient knowledge. } \\
\text { Needed specific instruction } \\
\text { at most operative steps }\end{array}$ & & $\begin{array}{l}\text { Knew all important } \\
\text { aspects of the } \\
\text { operation }\end{array}$ & & $\begin{array}{l}\text { Demonstrated familiarity } \\
\text { with all aspects of the } \\
\text { operation }\end{array}$ \\
\hline & 1 & 2 & 3 & 4 & 5 \\
\hline \multirow[t]{2}{*}{ Quality of final product } & Verypoor & & Competent & & Exceptional \\
\hline & 1 & 2 & 3 & 4 & 5 \\
\hline Overall Performance & Verypoor & & Competent & & Exceptional \\
\hline Maximum points & & & & & $(40)$ \\
\hline Select the final grade & & & & & () \\
\hline
\end{tabular}

* This parameter should be excluded when evaluating biopsies training. ** This parameter should be excluded when evaluating suture training 
through, for example, phrases like "a good pair of hands" to describe a resident with a good technical skill ${ }^{59}$. This method is not only subjective, but has been increasingly impractical in modern training programs ${ }^{53}$. Accordingly, as the observation by instructors becomes a valid and reliable assessment tool when performed with the adoption of fixed criteria (objective evaluation) ${ }^{53}$, surgical training programs must be able to objectively evaluate the gain of technical skills during training $53,54,59$.

Among the various objective methods adopted by the surgical community to measure technical skills, the Objective Structured Assessment of Technical Skills (OSATS) ${ }^{48,49}$ has been considered the gold standard tool ${ }^{54}$. OSATS is composed by a Task-Specific Checklists (TSC) and by GRS ${ }^{48,49}$. In this proposal, we adopted only the GRS as a tool for assessment and accreditation of the training process, because this scale can be used to analyze generic aspects of technical performance, without the need to develop specific lists for each procedure ${ }^{50}$. Moreover, it was shown by the same group that proposed OSATS 60 that the GRS used alone has better results (reliability and validity) compared with isolated TSC or TSC associated with GRS.

This training program was structured only to the development of some basic surgical skills. Therefore, it does not meet all the needs of training medical students, which should include the acquisition of other surgical skills 4,6,11-13.

The proposal of simulated teaching of the principles of surgery based on training with low-fidelity bench models made with organic material, rubberized boards and EVA plates is more a complementary alternative to the arsenal of existing programs and simulators, in order to better prepare medical students before contact with patients and encourage their career intentions.

\section{R E S U M O}

É notável a redução no número de estudantes de Medicina que escolhem a Cirurgia Geral como carreira. Neste contexto, novas possibilidades no campo do ensino cirúrgico devem ser desenvolvidas para combater este desinteresse. No presente estudo, um programa de treinamento cirúrgico baseado na aprendizagem em modelos de bancada de baixa fidelidade é delineado como uma alternativa complementar as diversas metodologias aplicadas no ensino das habilidades cirúrgicas básicas durante a graduação médica, bem como para desenvolver interesses pessoais na escolha da carreira.

Descritores: Educação. Estudantes. Cirurgia. Habilidade. Treinamento.

\section{REFERENCES}

1. Bland $\mathrm{KI}$, Isaacs $\mathrm{G}$. Contemporary trends in student selection of medical specialties: the potential impact on general surgery. Arch Surg. 2002;137(3):259-67.

2. Are C, Stoddard HA, O'Holleran B, Thompson JS. A multinational perspective on "lifestyle" and other perceptions of contemporary medical students about general surgery. Ann Surg. 2012;256(2):378-86.

3. Polk HC Jr. The declining interest in surgical careers, the primary care mirage, and concerns about contemporary undergraduate surgical education. Am J Surg. 1999;178(3):177-9.

4. Debas HT, Bass BL, Brennan MF, Flynn TC, Folse JR, Freischlag JA, et al. American Surgical Association Blue Ribbon Committee Report on Surgical Education: 2004. Ann Surg. 2005;241(1):1-8.

5. Fraher EP, Knapton A, Sheldon GF, Meyer A, Ricketts TC. Projecting surgeon supply using a dynamic model. Ann Surg. 2012;257(5):86772.

6. Stain SC, Cogbill TH, Ellison EC, Britt LD, Ricotta JJ, Calhoun JH, et al. Surgical training models: a new vision. Curr Probl Surg. 2012;49(10):565-623

7. Antiel RM, Thompson SM, Camp CL, Thompson GB, Farley DR. Attracting students to surgical careers: preclinical surgical experience. J Surg Educ. 2012;69(3):301-5.

8. Jiang DJ, Wen C, Yang AJ, Zhu ZL, Lei Y, Lan YJ, et al. Costeffective framework for basic surgical skills training. ANZ J Surg. 2013;83(6):472-6

9. Morris M, Caskey R, Mitchell M, Sawaya D. Surgical skills training restructured for the 21st century. J Surg Res. 2012;177(1):33-6.

10. Agha RA, Papanikitas A, Baum M, Benjamin IS. The teaching of surgery in the undergraduate curriculum. Part II-Importance and recommendations for change. Int J Surg. 2005;3(2):151-7.
11. Learning objectives for medical student education-guidelines for medical schools: report I of the Medical School Objectives Project. Acad Med. 1999;74(1):13-8

12. Schnabel KP, Boldt PD, Breuer G, Fichtner A, Karsten G, Kujumdshiev $S$, et al. A consensus statement on practical skills in medical school - a position paper by the GMA Committee on Practical Skills. GMS Z Med Ausbild. 2011;28(4):Doc58.

13. Brasil. Ministério da Educação. Conselho Nacional de Educação. Câmara de Educação Superior. Resolução CNE/CES N ${ }^{\circ} 4$, de 7 de novembro de 2001. Institui Diretrizes Curriculares Nacionais do Curso de Graduação em Medicina. Diário Oficial da União, 9 nov. 2001; Seção 1, p.38.

14. Forbes SS, Fitzgerald PG, Birch DW. Undergraduate surgical training: variations in program objectives and curriculum implementation across Canada. Can J Surg. 2006;49(1):46-50.

15. Engum SA. Do you know your students' basic clinical skills exposure? Am J Surg. 2003;186(2):175-81.

16. Collins AM, Ridgway PF, Hassan MS, Chou CW, Hill AD, Kneafsey B. Surgical instruction for general practitioners: how, who and how often? J Plast Reconstr Aesthet Surg. 2010;63(7):1156-62.

17. Serra M, Arévalo A, Ortega C, Ripoll A, Giménez N. Minor surgery activity in primary care. JRSM Short Rep. 2010;1(4):36.

18. Anastakis DJ, Regehr G, Reznick RK, Cusimano M, Murnaghan J, Brown $M$, et al. Assessment of technical skills transfer from the bench training model to the human model. Am J Surg. 1999;177(2):167-70

19. Carr J, Deal AM, Dehmer J, Amos KD, Farrell TM, Meyer AA, et al. Who teaches basic procedural skills: student experience versus faculty opinion. J Surg Res. 2012:177(2):196-200.

20. Hammond I, Karthigasu K. Training, assessment and competency in gynaecologic surgery. Best Pract Res Clin Obstet Gynaecol. 2006;20(1):173-87. 
21. Garcia C, Neuburg M, Carlson-Sweet K. A model to teach elliptica excision and basic suturing techniques. Arch Dermatol. 2006;142(4):526.

22. Franco D, Medeiros J, Grossi A, Franco T. Uso de língua bovina na prática de técnicas de sutura. Rev Col Bras Cir. 2008;35(6):442-4

23. Khalil PN, Siebeck M, Mutschler W, Kanz KG. The use of chicken legs for teaching wound closure skills. Eur J Med Res. 2009;14(10):459-60

24. Purim KSM. Oficina de cirurgia cutânea. Rev Col Bras Cir. 2010;37(4):303-5.

25. Bastos EM, Silva RD. Proposal of a synthetic ethylene-vinyl acetate bench model for surgical foundations learning. Suture training. Acta Cir Bras. 2011;26(2):149-52.

26. Denadai R, Souto LR. Organic bench model to complement the teaching and learning on basic surgical skills. Acta Cir Bras. 2012;27(1):88-94.

27. Denadai R, Kirylko L. Teaching basic plastic surgical skills on an alternative synthetic bench model. Aesthet Surg J. 2013;33(3):45861.

28. Denadai R, Bastos EM. The synthetic ethylene-vinyl acetate bench model. Dermatol Surg. 2012;38(2):288-9.

29. Scott DJ, Pugh CM, Ritter EM, Jacobs LM, Pellegrini CA, Sachdeva AK. New directions in simulation-based surgical education and training: validation and transfer of surgical skills, use of nonsurgeons as faculty, use of simulation to screen and select surgery residents, and long-term follow-up of learners. Surgery. 2011;149(6):73544.

30. Jensen $A R$, Wright $A S$, Levy $A E$, Mclntyre LK, Foy HM, Pellegrini CA, et al. Acquiring basic surgical skills: is a faculty mentor really needed? Am J Surg. 2009;197(1):82-8.

31. Moulton CA, Dubrowski A, Macrae H, Graham B, Grober E, Reznick R. Teaching surgical skills: what kind of practice makes perfect? a randomized, controlled trial. Ann Surg. 2006;244(3):400-9.

32. Dubrowski A, MacRae H. Randomised, controlled study investigating the optimal instructor: student ratios for teaching suturing skills. Med Educ. 2006;40(1):59-63.

33. Cannon-Bowers JA, Bowers C, Procci K. Optimizing learning in surgical simulations: guidelines from the science of learning and human performance. Surg Clin North Am. 2010;90(3):583-603.

34. Denadai R, Saad-Hossne R, Oshiiwa M, Bastos EM. Training on synthetic ethylene-vinyl acetate bench model allows novice medical students to acquire suture skills. Acta Cir Bras. 2012;27(3):271-8.

35. Denadai R, Oshiiwa M, Saad-Hossne R. Does bench model fidelity interfere in the acquisition of suture skills by novice medical students? Rev Assoc Med Bras. 2012;58(5):600-6.

36. Denadai R, Oshiiwa M; Saad-Hossne R. Teaching elliptical excision skills to novice medical students: a randomized controlled study comparing low- and high-fidelity bench models. Indian J Dermatol. 2012. [Epub ahead of print]

37. Denadai R, Toledo AP, Martinhão Souto LR. Basic plastic surgery skills training program on inanimate bench models during medical graduation. Plast Surg Int. 2012;2012:651863.

38. Vujevich JJ, Kimyai-Asadi A, Goldberg LH. The four angles of cutting Dermatol Surg. 2008;34(8):1082-4.

39. Khan MS, Bann SD, Darzi A, Butler PE. Use of suturing as a measure of technical competence. Ann Plast Surg. 2003;50(3):304-8.

40. Dastur N. DIY surgical knot-tying tool. Ann R Coll Surg Engl. 2009;91(3):268.

41. Hussain W, Mortimer NJ, Salmon PJ. Optimizing technique in elliptical excisional surgery: some pearls for practice. $\mathrm{Br} J$ Dermatol. 2009;161(3):697-8.

42. Silva RD, Souto LR. Evaluation of the diagnosis and treatment of non-melanoma skin cancer and its impacts on the prevention habits in a specific population of southeastern Brazil. Eur J Gen Med. 2011;8(4):291-301.

43. Shimizu R, Kishi K. Skin graft. Plast Surg Int. 2012;2012:563493.

44. Tschoi M, Hoy EA, Granick MS. Skin flaps. Surg Clin North Am. 2009;89(3):643-58.
45. Beard JD, Jolly BC, Newble DI, Thomas WE, Donnelly J, Southgate LJ. Assessing the technical skills of surgical trainees. Br J Surg. 2005;92(6):778-82.

46. Patel NP, Granick MS. Wound education: American medical students are inadequately trained in wound care. Ann Plast Surg. 2007;59(1):53-5.

47. Aldridge RB, Maxwell SS, Rees JL. Dermatology undergraduate skin cancer training: a disconnect between recommendations, clinical exposure and competence. BMC Med Educ. 2012:12:27.

48. Faulkner H, Regehr G, Martin J, Reznick R. Validation of an objective structured assessment of technical skill for surgical residents. Acad Med. 1996;71(12):1363-5

49. Reznick R, Regehr G, MacRae H, Martin J, McCulloch W. Testing technical skill via an innovative "bench station" examination. Am J Surg. 1997;173(3):226-30.

50. Khan MS, Bann SD, Darzi AW, Butler PE. Assessing surgical skill using bench station models. Plast Reconstr Surg. 2007;120(3):793800.

51. Picarella EA, Simmons JD, Borman KR, Replogle WH, Mitchell ME. "Do one, teach one" the new paradigm in general surgery residency training. J Surg Educ. 2011;68(2):126-9.

52. Vozenilek J, Huff JS, Reznek M, Gordon JA. See one, do one, teach one: advanced technology in medical education. Acad Emerg Med. 2004;11(11):1149-54.

53. Reznick RK. Teaching and testing technical skills. Am J Surg. 1993; 165(3):358-61

54. van Hove PD, Tuijthof GJ, Verdaasdonk EG, Stassen LP, Dankelman J. Objective assessment of technical surgical skills. Br J Surg 2010;97(7):972-87

55. Grober ED, Hamstra SJ, Wanzel KR, Reznick RK, Matsumoto ED, Sidhu RS, et al. The educational impact of bench model fidelity on the acquisition of technical skill: the use of clinically relevant outcome measures. Ann Surg. 2004;240(2):374-81.

56. Grober ED, Hamstra SJ, Wanzel KR, Reznick RK, Matsumoto ED, Sidhu RS, et al. Laboratory based training in urological microsurgery with bench model simulators: a randomized controlled tria evaluating the durability of technical skill. J Urol. 2004;172(1):37881.

57. Porte MC, Xeroulis G, Reznick RK, Dubrowski A. Verbal feedback from an expert is more effective than self-accessed feedback about motion efficiency in learning new surgical skills. Am J Surg. 2007:193(1):105-10.

58. Moorthy K, Munz Y, Sarker SK, Darzi A. Objective assessment of technical skills in surgery. BMJ. 2003;327(7422):1032-7.

59. Memon MA, Brigden D, Subramanya MS, Memon B. Assessing the surgeon's technical skills: analysis of the available tools. Acad Med. 2010;85(5):869-80.

60. Regehr G, MacRae H, Reznick RK, Szalay D. Comparing the psychometric properties of checklists and global rating scales for assessing performance on an OSCE-format examination. Acad Med. 1998:73(9):993-7.

Received on $12 / 11 / 2012$

Accepted for publication 15/01/2013

Conflict of interest: none.

Source of funding: none

\section{How to cite this article:}

Denadai R, Saad-Hossne R, Todelo AP, Kirylko L, Souto LRM. Lowfidelity bench models for training of basic surgical skills during undergraduate medical education. Rev Col Bras Cir. [periódico na Internet] 2014:41(2). Disponível em URL: http://www.scielo.br/rcbc

\section{Address for correspondence:}

Rafael Denadai

E-mail: denadai.rafael@hotmail.com 